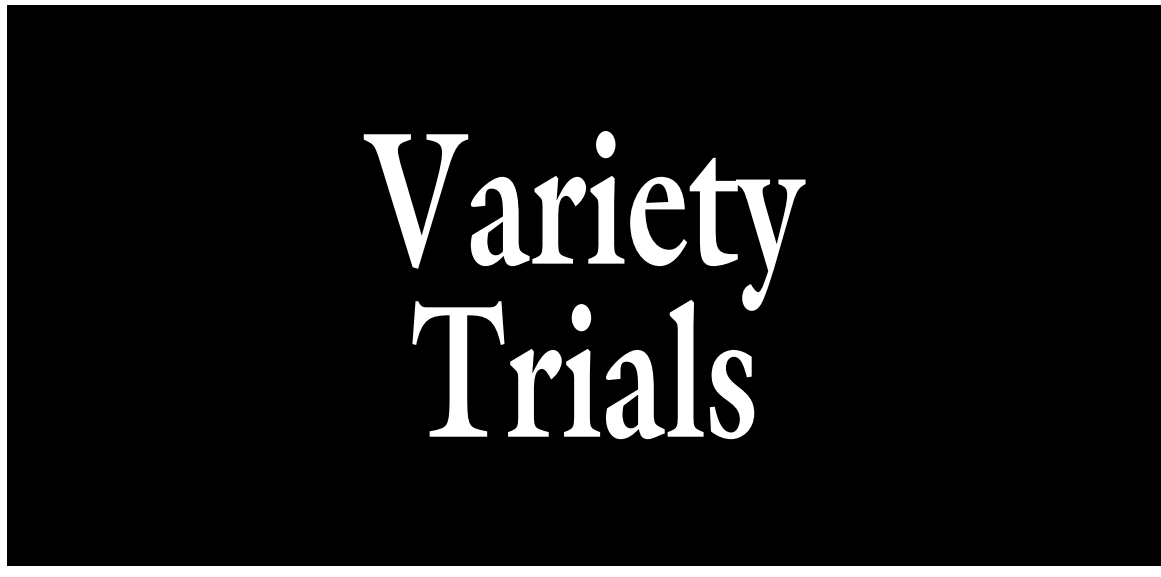

\title{
Identifying Bulb Fennel Cultivars Suitable for Production in the Northwest United States
}

\author{
Carol A. Miles ${ }^{1}$, Thomas S. Collins ${ }^{2}$, Yao $\mathrm{Mu}^{1}$, and \\ Travis Robert Alexander ${ }^{1,3}$
}

Additional INDEx wORDs. Foeniculum vulgave, internal cracking, phenolics, rotation crop, tenderness, yield

Summary. Two studies were performed in Mount Vernon, WA, to identify bulb fennel (Foeniculum $\times$ vulgare) cultivars and seeding practices best suited for the region. The first study evaluated 13 cultivars (Bronze, Finale, Florence, Genesi, Idillio, Orazio, Orion, Perfection, Preludio, Solaris, Tauro, Tenace, and Zefa Fino) over the course of 2 years; during the second year, the additional main factor of the seeding date was included. The second study evaluated three bulb fennel cultivars (Finale, Tauro, and Zefa Fino), four seeding dates (17 May, 31 May, 14 June, and 28 June 2018), and two planting methods (direct and transplant). Results of the two studies demonstrated that 'Finale', 'Orazio', 'Preludio', 'Solaris', and 'Tenace' had the greatest bulb production rate and yield and good bulb quality that met marketability standards. 'Genesi', 'Orion', and 'Perfection' had good bulb production during only 1 of the 2 years, whereas 'Bronze', 'Florence', 'Idillio', and 'Zefa Fino' had very low bulb productivity both years due to bolting. 'Perfection' and 'Tauro' exhibited internal cracking both years (incidence rates of $9.5 \%$ and $12.8 \%$, respectively). The first harvest was 94 to 112 days after seeding during the first study. Direct seeded bulb fennel required 32 fewer days to harvest than transplanted bulb fennel during the second study. The average bulb circumference was $28.1 \mathrm{~cm}$, with little variation between studies. Bulb tenderness for both studies was $617 \mathrm{~g}$-force, on average, and the soluble solids concentration of bulbs in both studies was $4.9 \%$. Ultra-high-performance liquid chromatography coupled with quadrupole time-of-flight mass spectrometry based on 38 tentatively identified compounds demonstrated no difference in the phenolic content of bulb fennel due to the cultivar. In conclusion, bulb fennel cultivars well-suited for production in northwest Washington were identified and direct seeding was demonstrated to be a better planting method than transplanting.

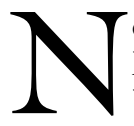

orthwest Washington is home to high-value vegetable, ornamental, and seed crop production. In recent years, however, the region has experienced critical losses of rotational processing crops such as pea (Pisum sativum), sweet corn (Zea mays convar. saccharata var. rugose), and carrot (Daucus carota) because they have been moved to regions with lower production costs.
Therefore, farmers in the region need new crops that are well-suited to the environment, which includes long summer daylength and a maritime climate, and that have good market value as well as fill the crop rotation niche. Bulb fennel is well-suited as a rotation crop in northwest Washington because it is not in the same family as the dominant regional crops, which include potato (Solanum tuberosum), cabbage (Brassica oleracea), and spinach (Spinacia oleracea) seed crops, daffodil (Narcissus sp.) and tulip (Tulipa sp.) bulbs, and pumpkins (Cucurbita sp.). Furthermore, bulb fennel has few nutrient requirements (Frost, 2015) and does not have many pests, which is conducive to sustainable agriculture production practices that are popular in the region.

Bulb fennel is a cool-season plant that is grown as an annual crop and considered native to the Mediterranean region. Sicily, Italy, is the primary bulb fennel production region in Europe, with the most recent statistics indicating an annual production of $350,000 \mathrm{t}$ per year and exports reaching Asia (Cserni et al., 2011). The average temperature in Sicily during bulb fennel seeding (November-December) is $55^{\circ} \mathrm{F}$, and during harvest (March-May) it is $63^{\circ} \mathrm{F}$ (Weatherbase, 2017). This is similar to the growing climate of Mount Vernon, WA, during the spring $\left(52{ }^{\circ} \mathrm{F}\right)$ and summer $\left(61{ }^{\circ} \mathrm{F}\right)$ production seasons (Washington State University, 2019). Currently, only a few farmers in northwest Washington are growing bulb fennel on a very small scale (less than 10 acres total); California is the largest producer in the United States, with 1236 acres reported several years ago (Kurtz and Mora, 2000). In Washington State, the wholesale price for organic bulb fennel is relatively high, $\approx \$ 0.91$ to $\$ 1.45$ per pound (D. Dempster, personal communication), so there is potential for increased production of this high-value crop.

The high market value of bulb fennel is also supported by its significant health benefits. Its unique flavor is due to an anethole essential oil (Kitajima et al., 1998). Transanethole is the most common compound of anethole found in bulb fennel, which has bioactive constituents that possess potent aldose reductase properties and antioxidant action (Barros et al., 2010; Dongare et al., 2012). It has been reported that bulb fennel contains phenolic substances (Faudale et al., 2008), which are compounds that, in general, have been associated with the prevention of diseases thought to be induced by oxidative stress, such as cardiovascular diseases, cancer, and inflammation (Aaby et al., 2005). Bulb fennel is also considered to have diuretic (increasing production of urine), 
stomachic (promoting the appetite or assisting digestion), and galactagogue (promoting lactation) properties (Barros et al., 2010). It is important to note that bulb fennel is a part of the Mediterranean diet, which has positive impacts on health that have been supported by numerous studies (Bower et al., 2016).

There has been no research to identify cultivars and seeding practices best suited for bulb fennel production in northwest Washington or elsewhere in the United States. Furthermore, the identification of bulb fennel qualities that contribute to increased marketability could increase production and marketing opportunities for regional growers. The objective of this study was to evaluate the suitability of bulb fennel for production in northwest Washington by assessing the cultivar performance on the basis of production and visual bulb quality parameters as well as bulb polyphenol content.

\section{Materials and methods}

EXPERIMENTAL DESIGN. Two studies were performed in Mount Vernon, WA (lat. $48^{\circ} 26^{\prime} 20.69^{\prime \prime} \mathrm{N}$, long. $\left.122^{\circ} 23^{\prime} 33.47^{\prime \prime} \mathrm{W}\right)$; weather data (mean air temperature, mean relative humidity, total precipitation, and total solar radiation) were recorded every $5 \mathrm{~s}$ and summarized every 15 min by a weather station located $\approx 0.4$ miles from the field (Washington State University, 2019). The field was certified organic at the beginning of the studies; however, in the middle of the second growing season, certification was lost due to the application of an

Received for publication 15 Apr. 2019. Accepted for publication 20 May 2019.

Published online 28 June 2019.

Technical support for this project was provided by Ed Scheenstra, Carolyn Klismith, Patricia Kreider, and Alexandra Arteritano. Funding support for this project from the Washington State University Emerging Research Issues Grant Program and the Northwest Agricultural Research Foundation is gratefully acknowledged.

${ }^{1}$ Department of Horticulture, Washington State University, 16650 State Route 536, Mount Vernon, WA 98273

${ }^{2}$ Deparment of Horticulture, Washington State University, 359 University Drive, Richland, WA 99352

${ }^{3}$ Corresponding author. E-mail: travis.alexander@ wsu.edu.

This is an open access article distributed under the CC BY-NC-ND license (https://creativecommons.org/ licenses/by-nc-nd/4.0/).

https://doi.org/10.21273/HORTTECH04372-19 herbicide to control a severe weed issue. The first study was a cultivar trial and the second study tested the seeding date and planting method. The first study included 13 bulb fennel cultivars (all bulb fennel cultivars offered for sale in the United States), and it was repeated the following year. During year 1 , cultivars were seeded on 2 May 2017, except for Genesi and Idillio which were seeded 5 June 2017 because of their reported susceptibility to bolting. Based on the results of year 1 , during year 2 , all 13 cultivars were seeded on two dates, 19 Apr. and 19 May. The experimental design during year 1 was a randomized complete block with four replications and 20 plants per plot. During year 2, the experimental design was a randomized split plot complete block with four replications and 20 plants per split plot. The main plot treatment was cultivar and the split plot treatment was seeding date.

The second study further explored the effects of the seeding date on yield and included four seeding dates, two planting methods, and three cultivars. The seeding dates were 17 May, 31 May, 14 June, and 28 June 2018, and the two planting methods were transplanting and direct seeding. The three bulb fennel cultivars were selected based on the results of the first study. They were selected to determine if bulb productivity and quality were affected by seeding date and/or method: one cultivar had high bulb productivity and quality (Finale), one cultivar had high bulb productivity and low quality (Tauro), and one cultivar had low bulb productivity and quality (Zefa Fino). The experimental design was a randomized split split plot complete block with four replications and 20 plants per split split plot. The main plot treatment was seeding date, the split plot treatment was cultivar, and the split split plot treatment was planting method. Plots with the same seeding dates were planted in the same rows to allow for irrigation to be applied on the whole row and to avoid saturation of empty plots with water and nutrients before seeding, which would have negatively affected germination and early seedling growth. An analysis of nutrient and chemical properties (e.g., $\mathrm{pH}$, percent organic matter, cation exchange capacity) of multiple randomly selected soil samples from the field before planting indicated no difference among beds; therefore, the effects of different plots on yield and quality of fennel bulbs were believed to be minimal.

Planting. During both studies, seeds for transplants were sown in 72cell plastic trays that were filled with seedling mix (Sunshine Mix \#3; Sun Gro Horticulture, Agawam, MA), one seed per cell, in a greenhouse maintained at 75 to $81{ }^{\circ} \mathrm{F}$ and $80 \%$ humidity. After 4 weeks, the seedlings were moved to an outside hardening area for $3 \mathrm{~d}$. Then, they were transferred to the field. During the second study, transplants and direct seeding treatments were seeded on the same

\begin{tabular}{clll}
\hline $\begin{array}{l}\text { Units } \\
\text { To convert U.S. to SI, } \\
\text { multiply by }\end{array}$ & U.S. unit & SI unit & $\begin{array}{l}\text { To convert SI to U.S., } \\
\text { multiply by }\end{array}$ \\
\hline 0.4047 & $\mathrm{acre}(\mathrm{s})$ & $\mathrm{ha}$ & $2.471 \mathrm{l}$ \\
29,574 & $\mathrm{fl} \mathrm{oz}$ & $\mu \mathrm{L}$ & $3.3814 \times 10^{-5}$ \\
29.5735 & $\mathrm{fl} \mathrm{oz}$ & $\mathrm{mL}$ & 0.0338 \\
0.3048 & $\mathrm{ft}$ & $\mathrm{m}$ & 3.2808 \\
3.7854 & $\mathrm{gal}$ & $\mathrm{L}$ & 0.2642 \\
9.3540 & gal $/ \mathrm{acre}$ & $\mathrm{L} \cdot \mathrm{ha}^{-1}$ & 0.1069 \\
2.54 & inch $(\mathrm{es})$ & $\mathrm{cm}$ & 0.3937 \\
25.4 & inch $(\mathrm{es})$ & $\mathrm{mm}$ & 0.0394 \\
0.0418 & langley(s) & $\mathrm{MJ} \cdot \mathrm{m}^{-2}$ & 23.9006 \\
0.4536 & $\mathrm{lb}$ & $\mathrm{kg}$ & 2.2046 \\
1.1209 & $\mathrm{lb} / \mathrm{acre}$ & $\mathrm{kg} \cdot \mathrm{ha}$ & 0.8922 \\
453.5924 & $\mathrm{lbf}$ & $\mathrm{gram}-\mathrm{force}$ & 0.0022 \\
1 & $\mathrm{micron}(\mathrm{s})$ & $\mu \mathrm{m}$ & 1 \\
0.0254 & $\mathrm{mil}(\mathrm{s})$ & $\mathrm{mm}$ & 39.3701 \\
1.6093 & $\mathrm{mile}(\mathrm{s})$ & $\mathrm{km}$ & 0.6214 \\
28.3495 & $\mathrm{oz}$ & $\mathrm{g}$ & 0.0353 \\
28,350 & $\mathrm{oz}$ & $\mathrm{mg}$ & $3.5274 \times 10^{-5}$ \\
0.9072 & ton $(\mathrm{s})$ & $\mathrm{t}$ & 1.1023 \\
$\left({ }^{\circ} \mathrm{F}-32\right) \div 1.8$ & ${ }^{\circ} \mathrm{F}$ & ${ }^{\circ} \mathrm{C}$ & $\left({ }^{\circ} \mathrm{C} \times 1.8\right)+32$ \\
& & &
\end{tabular}


day, in the greenhouse and in the field, respectively. During both studies, planting in the field was performed in double rows on a raised bed covered with black plastic mulch (1 mil thickness; Filmtech, Allentown, PA), with rows spaced 12 inches apart and plants spaced 8 inches apart in the row. For direct seeding, two seeds were sown in each planting hole at depths of 0.25 to 0.5 inch. After 4 weeks, if two seedlings emerged, then the weaker seedling was removed.

Fertilizer (Wil-Gro Organic 8N0.9P-3.3K; Wilbur Ellis, Aurora, CO) was applied before bed shaping at a rate of $100 \mathrm{lb} / \operatorname{acre}$ nitrogen $(\mathrm{N})$ for both studies. Supplemental fertilizer (Drammatic ONE 4N-1.7P$0.8 \mathrm{~K}$; Dramm Corp., Manitowoc, WI) was applied at $5.0 \mathrm{lb} /$ acre $\mathrm{N}$ via drip fertigation on 17 July 2017 during year 1 of study one, and at $2.1 \mathrm{lb} /$ acre $\mathrm{N}$ on 15 and 25 June and 5 July 2018 during both studies. For both studies, drip tape (8-inch emitter spacing, $57 \mathrm{gal} / \mathrm{h}$ flow rate; TTape model 508-08-340; Rivulis Irrigation, San Diego, CA) was installed on the center of the beds under the mulch at the same time that the beds were formed. Irrigation was applied three times per week for $\approx 75$ min per event during both studies, with the application reduced when precipitation occurred. The irrigation amount for study one was $11,285 \mathrm{gal} /$ acre in 2017 and 6512 $\mathrm{gal} / \mathrm{acre}$ in 2018, and it was 7053 gal/acre during study two.

Raised beds for both studies were $10 \mathrm{ft}$ center-to-center to allow for tractor cultivation between beds for weed control. Because the field site was certified organic, tractor cultivation minimized field plot maintenance labor and costs. However, weed control for both studies in 2018 was a major challenge because perennial tall oatgrass (Arrhenatherum elatius) occurred at very high levels in all plots. This weed was present in the field at low levels in 2017, and cultivation practices for weed control that year likely led to the spread throughout the field of the nutlets that are a primary propagule for this weed. This grass weed emerged from the planting holes in every plot and grew around the bulb fennel plants. Hand weeding was unsuccessful because pulling out the grass also resulted in the uprooting of bulb fennel seedlings. To save the experiments, the field was sprayed with a grass-specific herbicide (Select Max; Valent USA, Walnut Creek, CA), with the active ingredient clethodim applied at $0.12 \mathrm{lb} /$ acre on 25 June and at $0.09 \mathrm{lb} /$ acre on 23 July 2018.

Data collection. Plots were harvested once per week when fennel bulbs reached the maximum size for this location, which was a bulb circumference of approximately $\geq 25 \mathrm{~cm}$. The mean number of days until the first harvest was calculated for each cultivar, and the bulb production rate was calculated as the total number of bulbs harvested divided by the total number of plants per plot. During each harvest, foliage was trimmed 2 inches above the bulbs pursuant to market standards, and the total bulb weight and number were recorded for each plot. Bulb diameter and width were measured for five randomly selected representative bulbs at each harvest, and an average per plot was calculated. If fewer than five bulbs were harvested, then all bulbs were
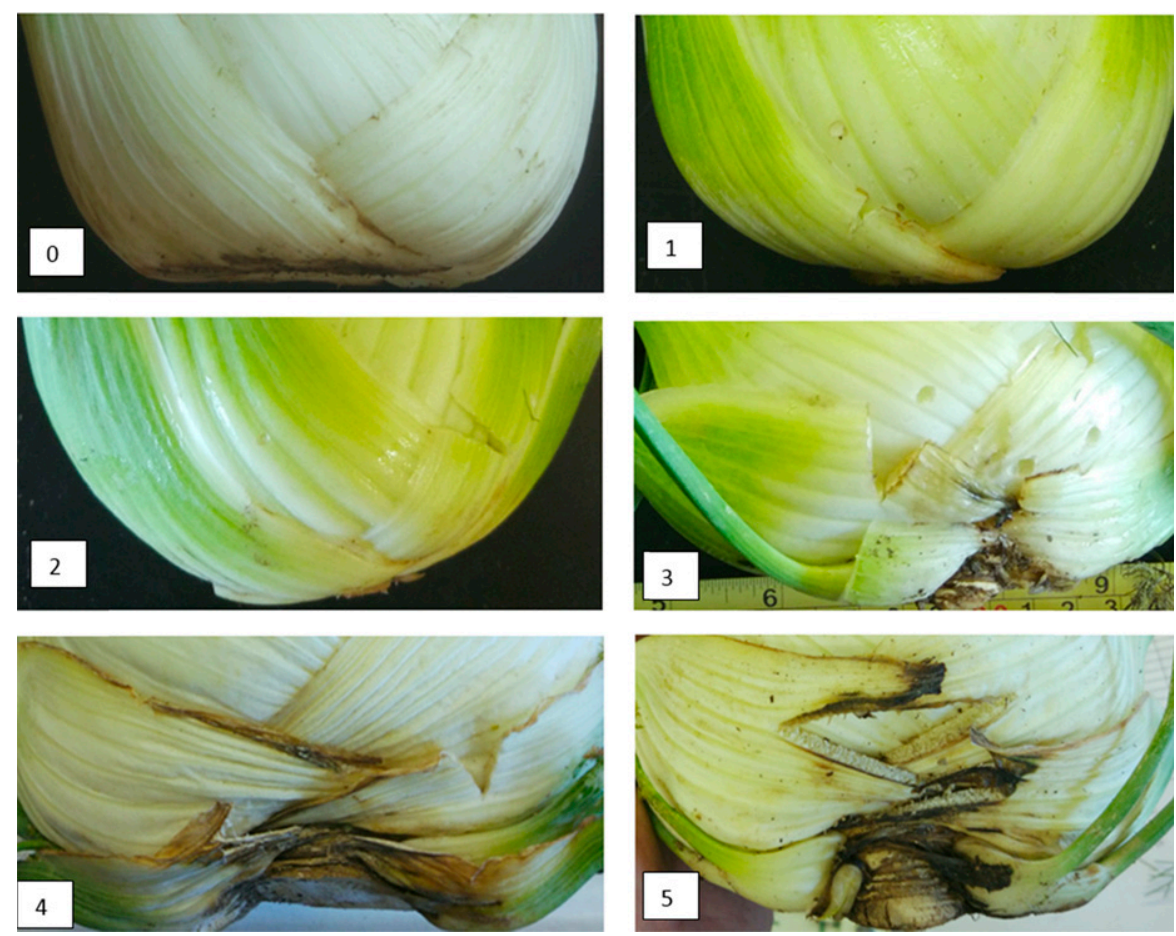

Fig. 1. Rating of basal cracking in bulb fennel on a scale of 0 to 5 , where $0=$ no condition observed, 1 = very good (slight signs of basal cracking), $2=\operatorname{good}($ signs are visible, no impact on marketing), 3 = acceptable (moderate signs of basal cracking, may impact marketing), $\mathbf{4}=$ poor (serious condition, may still be marketable after removing outside cracked leaves), and $5=$ very poor (the condition was very serious, bulb would not be marketable). 

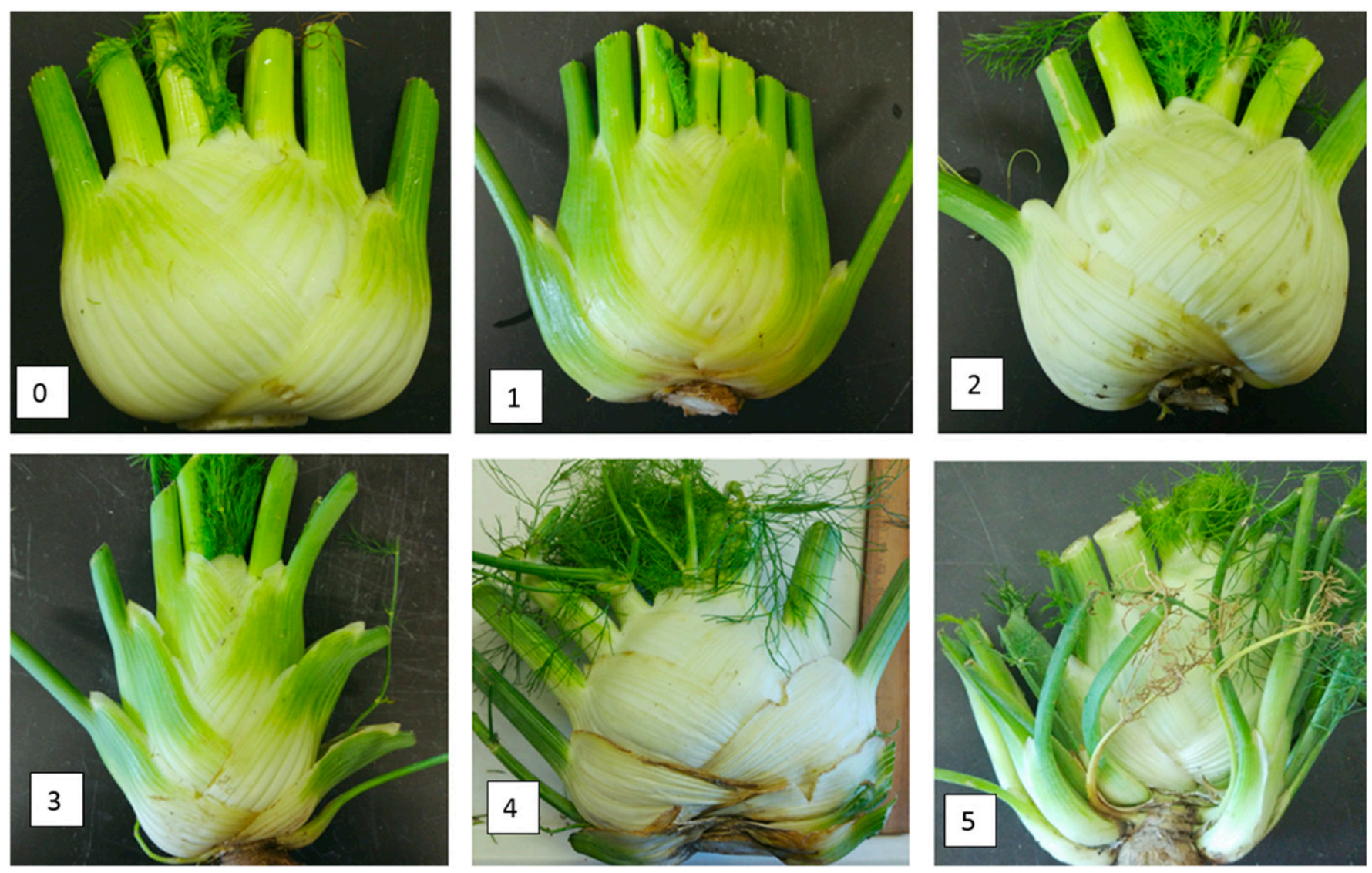

Fig. 2. Rating of branching for bulb fennel on a scale of 0 to 5 , where $0=$ no condition observed, $1=$ very good (slight signs of branching), 2 = good (signs are visible, no impact on marketing), 3 = acceptable (moderate signs of branching, may impact marketing), 4 = poor (serious condition, may still be marketable after removing extra branches), and $5=$ very poor $($ the condition was very serious, bulb would not be marketable).

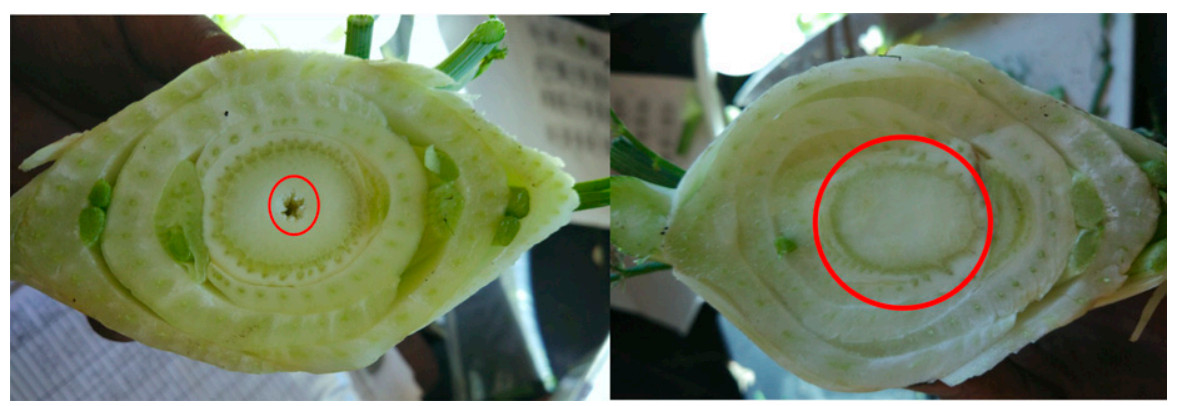

Fig. 3. Internal cracking in bulb fennel: present (left) and absent (right).

which internal cracking was recorded as present divided by the total number of bulbs evaluated (Fig. 3 ). The third leaf from the center was separated from each bulb, and tenderness was measured on the inner surface toward the base with a table-mounted pressure gauge (1-mm tip; LKG-2.5; Hunter Spring, Horsham, PA); one measurement was performed per leaf. The third leaf was then frozen $\left(6.8^{\circ} \mathrm{F}\right)$ for $48 \mathrm{~h}$, and the soluble solids concentration
(SSC) percentage was measured with a digital refractometer (Palm Abbe 201; MISCO, Cleveland, $\mathrm{OH}$ ).

At the time of each harvest performed during the first study in 2018, two representative bulbs from each plot were randomly selected for polyphenol analysis. The bulbs were cut in half horizontally, and then vertically; one quarter from the top and one quarter from the bottom were placed in a plastic bag, and the other quarters were discarded. Sealed bagged samples were stored at $-20{ }^{\circ} \mathrm{F}$ until all harvests were completed, 3 weeks maximum, and were transported to the Washington State University Wine Science Center in Richland. Frozen fennel bulb samples were ground in liquid nitrogen with a mortar and pestle, and the following is a summary of the polyphenol extraction that was performed. First, $2 \mathrm{~mL}$ of ethanol/formic acid ( $95: 5$ by volume) was added to $1000 \mathrm{mg}$ of frozen powdered material in a $15-\mathrm{mL}$ centrifuge tube and shaken overnight. Extracts were centrifuged at $3500 \mathrm{~g}_{\mathrm{n}}$ for $10 \mathrm{~min}$; then, the supernatant was stored at $39{ }^{\circ} \mathrm{F}$ until analysis $(\approx 5$ months). The extract volume was adjusted to $5.0 \mathrm{~mL}$ using methanol; then, solid-phase extraction (SPE) was used to remove lipids from the extracts before the chromatographic analysis. The SPE procedure was performed as follows: $2.5 \mathrm{~mL}$ of extract was placed on a water-primed $5-\mathrm{mL}$ reverse-phase SPE cartridge (Hypersep C18; Thermo Fisher Scientific, 
Waltham, MA). After the sample introduction, the cartridge was rinsed with $2 \mathrm{~mL}$ of water liquid chromatography-mass spectrometry (LCMS) solvent (Chromasolv, Thermo Fisher Scientific). The water fraction was added to the nonretained fraction from the sample introduction. The cartridge was then rinsed with $3 \mathrm{~mL}$ of methanol LC-MS solvent (Chromasolv) that was collected as a separate fraction. The fractions were prepared for analysis by filtering $\approx 1.5$ - $\mathrm{mL}$ aliquots through a 0.4 micron filter into a $2-\mathrm{mL}$ liquid chromatography vial. Blanks and standards containing known concentrations were placed between the samples to monitor quantification. External standards were purchased as follows: 5-O-caffeoylquinic acid (chlorogenic acid) (Sigma-Aldrich, St. Louis, MO), quercetin-3-O-rutinoside (rutin) (Sigma-Aldrich), and rosmarinic acid (Extrasynthese, Genay, France).

Ultra-high-performance liquid chromatography (UHPLC) was performed with a chromatograph (1290 Infinity II; Agilent Technologies, Santa Clara, CA) that was equipped with an automatic injector, vacuum degasser, and a reverse phase column $(50 \times 2 \mathrm{~mm}, 1.8 \mu \mathrm{m}$ particle size; Zorbax Rapid Resolution C18, Agilent Technologies). The mobile phase was a gradient prepared from $0.1 \%(\mathrm{v} / \mathrm{v})$ acetic acid in water $(\mathrm{A})$ and $0.05 \%(\mathrm{v} / \mathrm{v})$ acetic acid in methanol (B). The composition of the gradient was as follows: $0-1.0 \mathrm{~min}$, $3 \% \mathrm{~B} ; 9.0$ min $100 \% \mathrm{~B} ; 9.0-10.0 \mathrm{~min}$ $100 \% \mathrm{~B}$; and returning to initial conditions by $12.0 \mathrm{~min}$. The flow rate was $0.7 \mathrm{~mL} \cdot \mathrm{min}^{-1}$, and the injection volume was $5 \mu \mathrm{L}$. UHPLC effluent was analyzed using negative mode electrospray ionization coupled to quadrupole time-of-flight mass spectrometry (QTOF-MS) on a mass spectrometer (6545 Q-TOF; Agilent Technologies). Ionization was performed in negative mode to generate pseudomolecular parent ions $[\mathrm{M}-\mathrm{H}]-$ of compounds to be present in the samples. Compound identification was performed using authentic standards when available and using tandem mass spectrometry (MS/MS) fragmentation data as required.

Statistical analysis. During both studies, statistical analyses were performed using JMP software (version 12.2.0 for Windows; SAS Institute, Cary, NC). Levene's test was performed to confirm the assumption of homogeneity of variances. The least squares fit model was performed to evaluate the main effects and their two-way interactions for continuous data. The ordinal logistic fit model was performed to evaluate the main effects and their two-way interactions for ordinal data. Tukey's honestly significant difference test was used to compare treatment means at the $5 \%$ level. UHPLC/QTOF-MS results were analyzed using MassHunter (version 7.0; Agilent Technologies) and Mass Profiler Professional [MPP (version 13.1.1; Agilent Technologies)] software packages. The Molecular Feature Extractor algorithm in MassHunter was used to identify potential peaks, and peaks were aligned across all samples using the data alignment package in MPP. A discriminant analysis was conducted using XLSTAT 2015 (AddinSoft, New York, NY). The Metlin Tandem Mass Spectrometry database (Scripps Research, 2019) was used for preliminary identification of compound classes and for comparisons of MS/MS spectra for the identification of individual compounds.

\section{Results and Discussion}

Climate. Mean air temperature and mean relative humidity $(\mathrm{RH})$ were similar from the first seeding event to the final harvest during both years (Fig.
4). The overall mean temperature was $57^{\circ} \mathrm{F}$ and the overall mean relative humidity was $77 \% \mathrm{RH}$ for the growing season. Total precipitation during the growing season was low both years, but it was $27 \%$ greater in 2017 (1.9 inches) than in 2018 (1.5 inches) (Fig. 4). Total solar radiation was similar both years, but it was $6 \%$ greater in 2017 $\left(532 \mathrm{MJ} \cdot \mathrm{m}^{-2}\right)$ than in $2018(498$ $\mathrm{MJ} \cdot \mathrm{m}^{-2}$ ) (data not shown).

STUDY ONE. Plots were harvested three times in 2017, on 30 Aug., 7 Sept., and 15 Sept. In 2018, the first seeding was harvested once, on 5 Aug., and the second seeding was harvested twice, on 5 and 12 Sept. Remaining plants both years were not harvested due to bolting. 'Bronze' did not produce any bulbs either year, and 'Idillio' did not produce any bulbs from the first seeding in 2018; therefore, no results were presented for these cultivars. The 11 cultivars seeded on 2 May 2017 were first harvested 148 to $150 \mathrm{~d}$ after seeding, whereas the first harvest of the two cultivars seeded on 5 June was $15 \mathrm{~d}$ shorter at $133 \mathrm{~d}$ after seeding (data not shown). In 2018, on both seeding dates, all cultivars were harvested 109 to $112 \mathrm{~d}$ after seeding. The number of days until the first harvest was 21 to 41 fewer in 2018 than 2017, because we learned in 2017 that bulbs appeared to reach a maximum size under our management practices and environmental conditions, and no further gain in bulb size occurred after this point. This

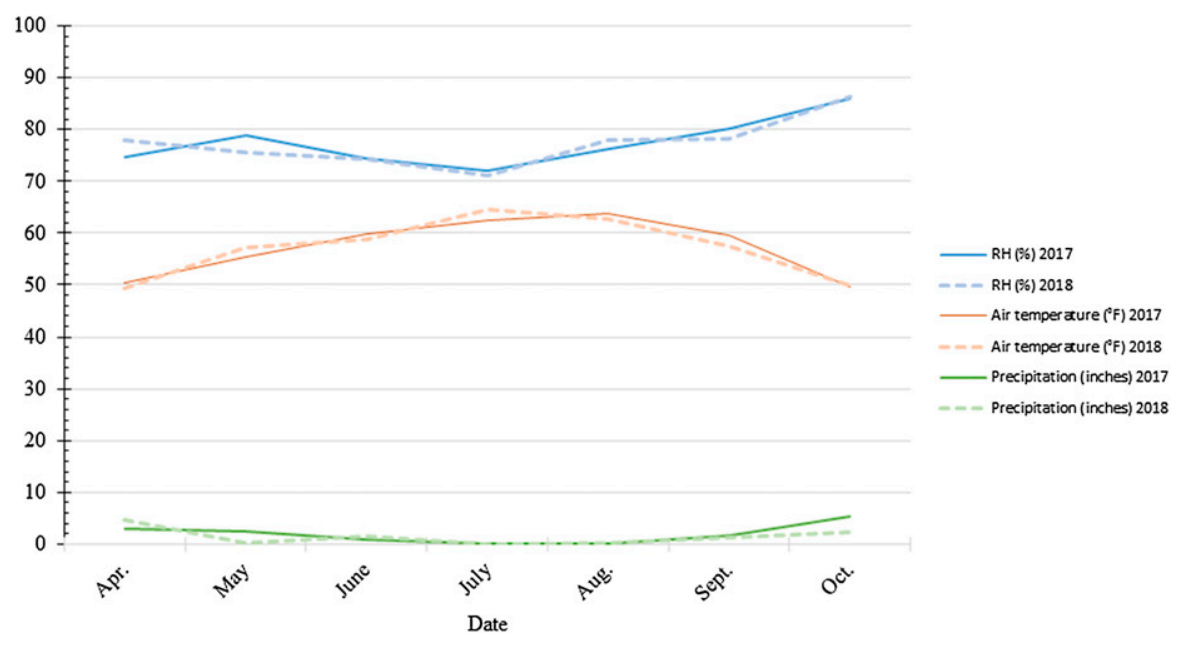

Fig. 4. Mean air temperature, mean relative humidity $(\mathrm{RH})$, and total precipitation at Washington State University Northwestern Washington Research and Extension Center in Mount Vernon, WA, from the first seeding event to the final harvests in $2017(\mathrm{~A})$ and $2018(\mathrm{~B}) ; 1$ inch $=25.4 \mathrm{~mm},\left({ }^{\circ} \mathrm{F}-32\right) \div 18={ }^{\circ} \mathrm{C}$. 
Table 1. Bulb production rate, bulb yield, weight per bulb, and bulb circumference for 12 bulb fennel cultivars grown in northwest Washington in 2017 and 2018; averages are provided for the two 2018 seeding dates as no significant difference was observed due to seeding date.

\begin{tabular}{|c|c|c|c|c|c|c|c|c|}
\hline \multirow[b]{2}{*}{ Cultivar } & \multicolumn{2}{|c|}{$\begin{array}{l}\text { Bulb production } \\
\text { rate }(\%)^{\mathrm{z}}\end{array}$} & \multicolumn{2}{|c|}{ Yield $(\mathrm{lb} / \text { acre })^{\mathrm{y}}$} & \multicolumn{2}{|c|}{ Bulb wt $(g)^{x}$} & \multicolumn{2}{|c|}{$\begin{array}{l}\text { Bulb circumference } \\
(\mathrm{cm})^{\mathrm{w}}\end{array}$} \\
\hline & $2017^{\mathrm{v}}$ & $2018^{\mathrm{u}}$ & 2017 & 2018 & 2017 & 2018 & 2017 & 2018 \\
\hline Florence & $43 \mathrm{ab}$ & $14 \mathrm{~b}$ & $3,320 \mathrm{~b}$ & $1,822 \mathrm{~d}$ & $145 \mathrm{e}$ & $252 \mathrm{~b}$ & $20.1 \mathrm{~b}$ & $23.6 \mathrm{ab}$ \\
\hline Genesi & $63 \mathrm{ab}$ & $41 \mathrm{~b}$ & $12,977 \mathrm{a}$ & $6,313 \mathrm{bcd}$ & $434 \mathrm{ab}$ & $334 \mathrm{ab}$ & $34.6 \mathrm{ab}$ & $20.9 \mathrm{~b}$ \\
\hline Idillio $^{\mathrm{s}}$ & $39 \mathrm{ab}$ & $6 \mathrm{~b}$ & $8,290 \mathrm{ab}$ & $5,816 \mathrm{bcd}$ & $439 a$ & $255 \mathrm{ab}$ & $29.7 \mathrm{ab}$ & $24.4 \mathrm{ab}$ \\
\hline Perfection & $53 \mathrm{ab}$ & $85 \mathrm{a}$ & $7,211 \mathrm{ab}$ & $14,509 \mathrm{abc}$ & $275 \mathrm{~cd}$ & $352 \mathrm{ab}$ & $23.9 \mathrm{ab}$ & $27.8 \mathrm{ab}$ \\
\hline Preludio & $61 \mathrm{ab}$ & $85 \mathrm{a}$ & $10,744 \mathrm{a}$ & $17,747 \mathrm{a}$ & $359 \mathrm{abc}$ & $458 \mathrm{ab}$ & $29.0 \mathrm{ab}$ & $31.9 \mathrm{ab}$ \\
\hline Solaris & $55 \mathrm{ab}$ & $90 \mathrm{a}$ & $10,570 \mathrm{a}$ & $17,782 \mathrm{a}$ & $405 \mathrm{ab}$ & $412 \mathrm{ab}$ & $29.4 \mathrm{ab}$ & $29.7 \mathrm{ab}$ \\
\hline Tauro & $67 \mathrm{ab}$ & $92 \mathrm{a}$ & $12,698 \mathrm{a}$ & $21,195 a$ & $397 \mathrm{ab}$ & $480 \mathrm{a}$ & $28.0 \mathrm{ab}$ & $30.2 \mathrm{ab}$ \\
\hline Tenace & $72 \mathrm{a}$ & $84 \mathrm{a}$ & $12,571 \mathrm{a}$ & $15,765 \mathrm{ab}$ & $365 \mathrm{abc}$ & $388 \mathrm{ab}$ & $28.0 \mathrm{ab}$ & $29.2 \mathrm{ab}$ \\
\hline
\end{tabular}

${ }^{\mathrm{z}}$ Bulb production rate calculated as the total number of bulbs formed divided by the total number of plants in the plot (reported as percentage).

yield calculated by multiplying the estimated production potential constant of 48,214 [the maximum number of bulbs per acre when spacing is 8 inches ( $20.3 \mathrm{~cm}$ ) in-row, two rows per bed, and $5 \mathrm{ft}(1.5 \mathrm{~m})$ between beds] by the measured bulb weight and calculated bulb production rate; $1 \mathrm{lb} / \mathrm{acre}=1.1209 \mathrm{~kg} \cdot \mathrm{ha}{ }^{-1}$.

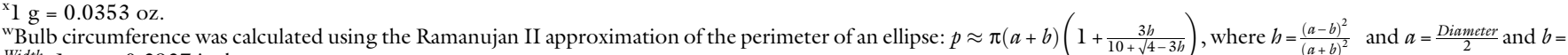
$\frac{\text { Width }}{2} ; 1 \mathrm{~cm}=0.3937$ inch.

vAll cultivars seeded 2 May, except Genesi and Idillio, which were seeded 5 June.

"All cultivars seeded on 19 Apr. and 19 May; data were combined because there was no significant variation due to the seeding date.

tDifferent letters within a column indicate differences in means as compared by Tukey's honest significant difference test at a $5 \%$ level of significance.

s'Bulbs were not formed for the first seeding of 'Idillio' in 2018; therefore, 2018 data for this cultivar are from the second seeding date.

outcome indicated a need for growers to familiarize themselves with bulb size for their location and management practices.

Bulb production rates did not differ due to the seeding date in $2018(P=0.79)$ and were greater in 2018 than in 2017 (65\% and 56\%, respectively) (Table 1 ), likely due to earlier seeding dates in 2018 that led to a reduction in bolting (data not shown). The bulb production rate differed due to the cultivar. It was greater in 2018 than in 2017 for the nine most productive cultivars $(84 \%$ and $62 \%$, respectively); however, it was lower in 2018 than in 2017 for the three least productive cultivars (9\% and 39\%, respectively) (Table 1). 'Zefa Fino', 'Idillio', and 'Florence' had the lowest bulb production rate both years ( $24 \%$ on average), whereas 'Genesi' was low only in 2018. These results suggest 'Zefa Fino', 'Idillio', and 'Florence' generally do not form bulbs at this location, whereas 'Genesi' may be more sensitive to environmental factors than the nine cultivars that were consistent during the 2 years.

Results regarding the bulb total yield and bulb weight were similar to results for the bulb production rate. Bulb total yield and bulb weight did not differ due to the seeding date in $2018(P=0.67$ and $P=0.98$, respectively), and the bulb total yield in 2018 was $45 \%$ greater than in 2017 (average, 13,563 and $9369 \mathrm{lb} / \mathrm{acre}$, respectively). The bulb total yield differed due to cultivar. 'Tauro', 'Orazio', 'Finale', 'Tenace', 'Preludio', and 'Solaris' were high-yielding both years (average, 15,213 lb/ acre), whereas 'Florence', 'Zefa Fino', and 'Idilio' were low-yielding both years (average, $4187 \mathrm{lb} /$ acre) (Table $1)$. Bulb weight was $13 \%$ greater in 2018 than in 2017 (379 and $336 \mathrm{~g}$, respectively). An increased number of harvestable bulbs and bulb weight in 2018 may have been, at least partly, due to changes in the supplemental $\mathrm{N}$ fertilizer application that year, which may better-suit the needs of bulb fennel. Supplemental N was first applied 1 month earlier in 2018 than in 2017, and the application in 2018 was split over three dates, with an application every $10 \mathrm{~d}$; in 2017, there was one application. Furthermore, slightly more supplemental $\mathrm{N}$ was applied in 2018 than in 2017 (6.2 and $5.0 \mathrm{lb} /$ acre $\mathrm{N}$, respectively).

Bulb circumference did not differ due to the seeding date in 2018 $(P=0.63)$, and it was also similar in 2017 and 2018 (28.3 and $27.6 \mathrm{~cm}$, respectively) (Table 1 ). The bulb circumference differed due to the cultivar. In 2017, 'Finale' produced bulbs with the largest circumference $(40.3$ $\mathrm{cm}$ ); however, this was statistically equivalent to all other cultivars except Florence and Zefa Fino $(20.6 \mathrm{~cm}$, on average). In 2018, 'Orazio' produced bulbs with the largest circumference $(32.9 \mathrm{~cm})$; however, this was statistically equivalent to all other cultivars except Genesi $(20.9 \mathrm{~cm})$. Although basal cracking differed due to the cultivar both years and due to the seeding date in $2018(P=0.01)$, all cultivars had a basal cracking rating that indicated no negative impact on marketability $(<3)$ (Table 2 ), with the exception of Tenace in 2018 (3.3 rating). In 2017, the incidence of internal cracking averaged $2.4 \%$ for all cultivars except Perfection $(14.0 \%)$; in 2018 , the incidence of internal cracking averaged $1.4 \%$ for all cultivars expect Tauro $(17.5 \%)$ (Table $2)$. The incidence of internal cracking did not differ due to the seeding date in $2018(P=0.53)$. Branching differed due to the cultivar in $2017(P=$ $0.01)$, but not in $2018(P=0.17)$, and it did not differ due to the seeding date in $2018(P=0.06)$. Both years, all cultivars had a rating less than 3, which would not impact 
Table 2. Basal cracking, incidence of internal cracking, branching, tenderness, and soluble solids concentration (SSC) for 12 bulb fennel cultivars grown in northwest Washington in 2017 and 2018.

\begin{tabular}{|c|c|c|c|c|c|c|c|c|c|c|c|c|}
\hline \multirow[b]{3}{*}{ Cultivar } & \multicolumn{3}{|c|}{ Basal cracking $(0-5)^{\mathrm{z}}$} & \multirow{2}{*}{\multicolumn{2}{|c|}{$\begin{array}{c}\text { Internal cracking } \\
(\%)^{\mathrm{y}}\end{array}$}} & \multirow{2}{*}{\multicolumn{2}{|c|}{$\begin{array}{l}\text { Branching } \\
\quad(0-5)^{\mathrm{z}}\end{array}$}} & \multicolumn{3}{|c|}{$\begin{array}{l}\text { Tenderness (gram- } \\
{\text { force })^{\mathrm{x}}}\end{array}$} & \multirow{2}{*}{\multicolumn{2}{|c|}{ SSC (\%) }} \\
\hline & \multirow[b]{2}{*}{$2017^{w}$} & \multicolumn{2}{|c|}{$2018^{v}$} & & & & & & & & & \\
\hline & & 1 & 2 & 2017 & 2018 & 2017 & 2018 & 2017 & 1 & 2 & 2017 & 2018 \\
\hline Finale & $0.8 \mathrm{abc}^{\mathrm{u}}$ & $1.3 \mathrm{ab}$ & $1.3 \mathrm{~b}$ & $0.0 \mathrm{~b}$ & $7.5 \mathrm{ab}$ & $1.5 \mathrm{ab}$ & 1.8 & 1074 & 624 & 514 & 5.6 & 4.9 \\
\hline Florence & $0.5 \mathrm{bc}$ & $2.0 \mathrm{ab}$ & $1.0 \mathrm{~b}$ & $0.0 \mathrm{~b}$ & $9.8 \mathrm{ab}$ & $2.6 \mathrm{ab}$ & 2.6 & 917 & 560 & 513 & 5.8 & 5.0 \\
\hline Genesi & $1.0 \mathrm{abc}$ & $1.3 \mathrm{ab}$ & $1.3 \mathrm{ab}$ & $0.0 \mathrm{~b}$ & $0.0 \mathrm{~b}$ & $1.6 \mathrm{ab}$ & 2.5 & 1041 & 757 & 513 & 4.8 & 5.1 \\
\hline Orion & $1.0 \mathrm{abc}$ & $1.8 \mathrm{ab}$ & $2.0 \mathrm{ab}$ & $0.0 \mathrm{~b}$ & $7.5 \mathrm{ab}$ & $1.0 \mathrm{~b}$ & 2.0 & 1024 & 723 & 583 & 5.3 & 5.2 \\
\hline Perfection & $0.4 \mathrm{c}$ & $0.5 \mathrm{~b}$ & $1.5 \mathrm{ab}$ & $14.0 \mathrm{a}$ & $5.0 \mathrm{~b}$ & $2.7 \mathrm{ab}$ & 1.9 & 1093 & 763 & 569 & 5.4 & 4.8 \\
\hline Preludio & $1.2 \mathrm{abc}$ & $1.0 \mathrm{ab}$ & $1.3 \mathrm{~b}$ & $0.0 \mathrm{~b}$ & $2.5 \mathrm{~b}$ & $1.9 \mathrm{ab}$ & 2.0 & 1190 & 629 & 540 & 5.7 & 5.3 \\
\hline Solaris & $1.0 \mathrm{abc}$ & $1.3 \mathrm{ab}$ & $1.5 \mathrm{ab}$ & $0.0 \mathrm{~b}$ & $2.5 \mathrm{~b}$ & $1.8 \mathrm{ab}$ & 1.6 & 1098 & 652 & 556 & 5.4 & 4.8 \\
\hline Tauro & $1.3 \mathrm{abc}$ & $1.5 \mathrm{ab}$ & $1.8 \mathrm{ab}$ & $8.0 \mathrm{ab}$ & $17.5 \mathrm{a}$ & $2.0 \mathrm{ab}$ & 1.9 & 1188 & 680 & 518 & 5.2 & 4.9 \\
\hline Tenace & $1.1 \mathrm{abc}$ & $1.0 \mathrm{ab}$ & $3.3 \mathrm{a}$ & $4.0 \mathrm{~b}$ & $0.0 \mathrm{~b}$ & $1.4 \mathrm{ab}$ & 1.5 & 1047 & 681 & 503 & 5.1 & 4.8 \\
\hline
\end{tabular}

${ }^{\mathrm{z}}$ Basal cracking and branching were graded on a scale of 0 to 5 , where $0=$ no condition observed, $1=$ very good (slight signs of basal cracking or branching), $2=$ good (signs are visible, no impact on marketing), $3=$ acceptable (moderate signs of basal cracking or branching, may impact marketing), $4=$ poor (serious condition, may still be marketable after removing outside cracked leaves or extra branches), and $5=$ very poor (the condition was very serious, bulb would not be marketable).

Internal cracking scored as absent or present; the incidence of internal cracking was calculated as the number of bulbs in which internal cracking was recorded as present divided by the total number of bulbs evaluated.

${ }^{x} 1 \mathrm{~g}$-force $=0.0022 \mathrm{lbf}$.

${ }^{\text {wAll }}$ cultivars seeded 2 May, except Genesi and Idillio, which were seeded 5 June.

"All cultivars seeded on 19 Apr. (1) and 19 May (2); data were combined when there was no significant variation due to the seeding date.

"Different letters within a column indicate differences in means as compared by Tukey's honest significant difference test at a $5 \%$ level of significance.

'Bulbs were not formed for the first seeding of 'Idillio' in 2018; therefore, no data were collected for this cultivar.

marketability, except for 'Zefa Fino' in 2017 , which had a rating of 3.8 (Table 2). Bulb tenderness differed due to the seeding date in 2018 (666 and $54 \mathrm{l}$ g-force, respectively; $P<$ 0.0001 ), and bulbs were less tender overall in 2017 (1065 g-force); however, there were no differences due to the cultivar either year (Table 2). Bulbs were likely less tender in 2017 due to the harvest being 1 month later compared with 2018. SSC did not differ due to the cultivar either year $(P=0.14$ and $P=0.20)$ or the seeding date in $2018(P=0.66)$; on average, these SSC rates were $5.4 \%$ in 2017 and $4.9 \%$ in 2018 (Table 2).

A chromatography-mass spectrometry analysis was performed for 11 of the 13 bulb fennel cultivars evaluated because insufficient extracts of the cultivars Bronze and Zefa Fino were available due to low bulb productivity. The initial alignment of the UHPLC/QTOF-MS data resulted in a list of 787 entities (based on mass and associated retention time). The list of potential compounds was reduced by screening out entities that were not present in all replicates of at least one sample type, thus reducing the number of entities to 122 . The Metlin Metabolite database was used to sort these entities into compound classes; then, identification was based on mass matches with compounds in the online database using a tolerance of 30 ppm (Scripps Research, 2019). Preference was given to compounds previously reported in bulb fennel; when multiple possible matches were present without a clear reason to select one match, a chemical formula was listed instead. Multiple matching identifications are included in Table 3 because many of the compounds may be present as multiple structural or stereoisomers (e.g., 3 -feruloyl quinic acid and 5-feruloyl quinic). Regarding the score or observations plot (Fig. 5A), the 95\% confidence ellipses for the individual bulb fennel cultivars generally overlap, indicating that the phenolic content of the bulb fennel cultivars did not vary significantly across most of the cultivars in this study. However, there were a few individual cultivars that could be differentiated. For example, the ellipse for 'Orion' does not overlap with the ellipses for 'Tenance', 'Genesis', 'Perfection', and 'Finale'. Similarly, the ellipse for 'Finale' does not overlap with that of 'Florence' and 'Idillio', and it can be differentiated from 'Tenance'. The loading or variables plot (Fig. 5B) showed the relationships among the compounds used to conduct the discriminant analysis and the samples in the analysis. Most of the compounds are on the positive side of the first axis of the plot, meaning they are more closely correlated with the samples that appear on the positive side of the score plot. The samples on the left or negative side of the score plot would be negatively correlated with these compounds (i.e., they would generally have lower levels of these compounds). Given the sizes of the $95 \%$ confidence ellipses, it is also clear that the variability in the content of phenolic compounds in these extracts is large relative to the differences in phenolic content among the various cultivars.

Most of the compounds used for the discriminant analysis have been previously found in bulb fennel or other plants. For example, quinic acid and its caffeic, ferulic, and p-coumaric derivatives have been widely found in bulb fennel (Badgujar et al., 2014; Ferioli et al., 2017; Rather et al., 2016), as has the presence of multiple isomers of these derivatives, including four isomers of caffeoyl-quinic acid and feruloyl-quinic acid (Pacifico et al., 2018) and three isomers of dicaffeoyl-quinic acid (Rather et al., 2016). Caffeoyl-feruloyl quinic acid derivatives have been previously found 
Table 3. Neutral mass $[M]$, retention time (RT), and tentative identifications (ID) of the 38 compounds used in the discriminant analysis (DA) of 11 bulb fennel cultivars (Finale, Florence, Genesi, Idillio, Orazio, Orion, Perfection, Preludio, Solaris, Tauro, and Tenace) seeded in northwest Washington in 2018 and the correlations of the first two uncorrelated variables (PCl and PC2) that explain the greatest variance in the dataset.

\begin{tabular}{|c|c|c|c|c|}
\hline$[\mathbf{M}]$ & RT (s) & ID & PCl & PC2 \\
\hline 122.0363 & 2.12 & $\mathrm{C}_{7} \mathrm{H}_{6} \mathrm{O}_{2}$ (hydroxybenzaldehyde) & 0.064 & -0.109 \\
\hline 134.072 & 5.17 & Chavicol & 0.448 & 0.419 \\
\hline 138.0307 & 3.53 & $\mathrm{C}_{7} \mathrm{H}_{6} \mathrm{O}_{3}$ (dihydroxybenzaldehyde) & 0.329 & -0.095 \\
\hline 138.0311 & 2.14 & $\mathrm{C}_{7} \mathrm{H}_{6} \mathrm{O}_{3}$ (salicylic acid $)$ & 0.220 & -0.164 \\
\hline 180.0419 & 2.35 & Caffeic acid & 0.250 & 0.017 \\
\hline 182.0566 & 2.15 & $\mathrm{C}_{9} \mathrm{H}_{10} \mathrm{O}_{4}$ & 0.209 & -0.043 \\
\hline 192.0619 & 3.28 & Quinic acid & 0.097 & -0.017 \\
\hline 192.0635 & 3.71 & Quinic acid & 0.089 & -0.253 \\
\hline 192.0637 & 2.89 & Quinic acid & -0.007 & 0.280 \\
\hline 192.0638 & 2.35 & Quinic acid & 0.033 & -0.088 \\
\hline 284.1242 & 3.65 & Phenylethyl glucose & 0.330 & -0.017 \\
\hline 326.0999 & 2.54 & $p$-coumaroyl glucose & 0.133 & -0.208 \\
\hline 326.1156 & 4.74 & $\mathrm{C}_{19} \mathrm{H}_{18} \mathrm{O}_{5}$ & 0.182 & -0.218 \\
\hline 338.1149 & 4.42 & $p$-coumaroyl quinic acid & 0.112 & -0.078 \\
\hline 338.1152 & 4.39 & $p$-coumaroyl quinic acid & -0.005 & 0.011 \\
\hline 338.1163 & 4.76 & $p$-coumaroyl quinic acid & -0.010 & -0.243 \\
\hline 356.1108 & 2.58 & Feruloyl glucose & 0.304 & -0.286 \\
\hline 368.1086 & 3.50 & Feruloyl quinic acid & 0.576 & -0.250 \\
\hline 368.1106 & 3.69 & Feruloyl quinic acid & 0.293 & 0.334 \\
\hline 368.1106 & 3.80 & Feruloyl quinic acid & 0.113 & 0.372 \\
\hline 368.1109 & 3.27 & Feruloyl quinic acid & 0.257 & 0.292 \\
\hline 372.1058 & 3.11 & Dihydroferulic acid glucuronide & 0.357 & -0.177 \\
\hline 462.0809 & 4.49 & Kaempferol glucuronide & 0.006 & -0.344 \\
\hline 462.0832 & 4.77 & Kaempferol glucuronide & 0.115 & -0.117 \\
\hline 464.0937 & 4.26 & Quercetin-3-glucoside & 0.087 & -0.047 \\
\hline 464.1041 & 7.11 & Quercetin-3-galactoside & 0.087 & -0.112 \\
\hline 466.106 & 7.11 & $\mathrm{C}_{21} \mathrm{H}_{22} \mathrm{O}_{12}$ & -0.138 & -0.019 \\
\hline 494.1062 & 4.33 & $\mathrm{C}_{22} \mathrm{H}_{22} \mathrm{O}_{13}$ & 0.023 & -0.056 \\
\hline 516.1442 & 3.04 & Dicaffeoylquinic acid & 0.065 & -0.021 \\
\hline 516.1474 & 2.99 & Dicaffeoylquinic acid & 0.130 & 0.105 \\
\hline 516.1477 & 2.40 & Dicaffeoylquinic acid & 0.210 & 0.104 \\
\hline 530.1448 & 2.01 & Caffeoyl-feruloyl quinic acid & -0.180 & 0.093 \\
\hline 552.1807 & 3.43 & Resveratrol diglucose & 0.421 & -0.262 \\
\hline 552.1838 & 3.60 & Resveratrol diglucose & 0.204 & -0.289 \\
\hline 578.1961 & 4.39 & $\mathrm{C}_{28} \mathrm{H}_{34} \mathrm{O}_{13}$ & 0.350 & -0.098 \\
\hline 578.1999 & 4.47 & $\mathrm{C}_{28} \mathrm{H}_{34} \mathrm{O}_{13}$ & 0.301 & -0.168 \\
\hline 604.1767 & 4.71 & Malonyl glucose derivative of 326.1156 & 0.280 & 0.040 \\
\hline 604.1767 & 4.79 & Malonyl glucose derivative of 326.1156 & 0.214 & -0.134 \\
\hline
\end{tabular}

in chinese sweet potato [Ipomoea batatas (Zheng and Clifford, 2008)], but not in bulb fennel. In bulb fennel, quercetin and kaempferol glycosides and glucuronides have also been found (Badgujar et al., 2014; Ferioli et al., 2017; Rather et al., 2016). Similarly, resveratrol mono-glucosides and di-glucosides have been discovered in bulb fennel (Rather et al., 2016). Compounds with neutral masses of 326.1156 and 604.1767 are related, the mass spectra for these compounds frequently include both masses, and the neutral loss between the two masses corresponds to the loss of a malonyl glucoside moiety. Chavicol is the phenol analog to estragol (methyl chavicol), which is a major phenylpropanoid in bulb fennel oil (Pouryousef, 2014).

STUDY Two. Plots were harvested once per week from 14 Aug. until 11 Oct. 2018, for a total of 10 harvests. Although growers would likely harvest a planting only once or twice, this harvest schedule was followed due to the multiple seeding dates. Plants that were not harvested either did not form a bulb or had bolted. Plant stand was similar for the two planting methods $(79 \%$ for transplanting and $81 \%$ for direct seeding) and was impacted by the presence of tall oatgrass weeds in the planting holes. There was a significant interaction of planting method $\times$ seeding date $(P=0.02)$ for the number of days from seeding to first harvest (Table 4). Direct seeded bulb fennel on all four seeding dates, on average, had a shorter seeding to first harvest period $(94 \mathrm{~d})$ than transplanted bulb fennel seeded on 31 May, 14 June, and 28 June 2018 $(126 \mathrm{~d})$. There was no significant variation in the number of days from seeding to first harvest due to interactions of planting method or date with cultivar $(P=0.46$ and $P=0.50$, respectively) or due to the main effect of cultivar itself $(P=0.35)$ (data not shown).

There was a significant interaction of cultivar $\times$ planting method for the bulb production rate (Table 4). Direct seeded and transplanted 'Zefa Fino' had a lower bulb production rate $(34 \%$ on average) than direct seeded and transplanted 'Finale' and 'Tauro' $(80 \%$ on average). Yield did not differ due to planting method $(P=0.50)$ or seeding date $(P=$ $0.18)$, but there was a difference due to the cultivar (Table 5). As expected, due to its lower bulb production rate, 'Zefa Fino' had a lower yield (6810 $\mathrm{lb} / \mathrm{acre}$ ) than 'Tauro' and 'Finale' $(18,522 \mathrm{lb} /$ acre on average $)$. Bulb weight did not differ due to the planting method $(P=0.53)$, seeding date $(P=0.59)$, or cultivar $(P=0.24)$, and it was $437 \mathrm{~g}$ on average (data not shown). The interaction of planting method $\times$ seeding date was found to be significant for bulb circumference (Table 6). Transplanting on 31 May resulted in a larger bulb circumference $(29.7 \mathrm{~cm})$ than direct seeding on the same day $(26.6 \mathrm{~cm})$, transplanting and direct seeding on 14 June resulted in similar circumferences $(28.8 \mathrm{~cm})$, and transplanting on 28 June resulted in a smaller circumference $(25.6 \mathrm{~cm})$ than direct seeding on the same day $(29.5 \mathrm{~cm})$. Overall, the average bulb circumference was $28.3 \mathrm{~cm}$, and the range was 25.6 to $29.7 \mathrm{~cm}$; therefore, although statistically significant, the difference in bulb circumference likely would have no impact on bulb marketability.

Basal cracking did not differ due to planting method $(P=0.86)$ and 


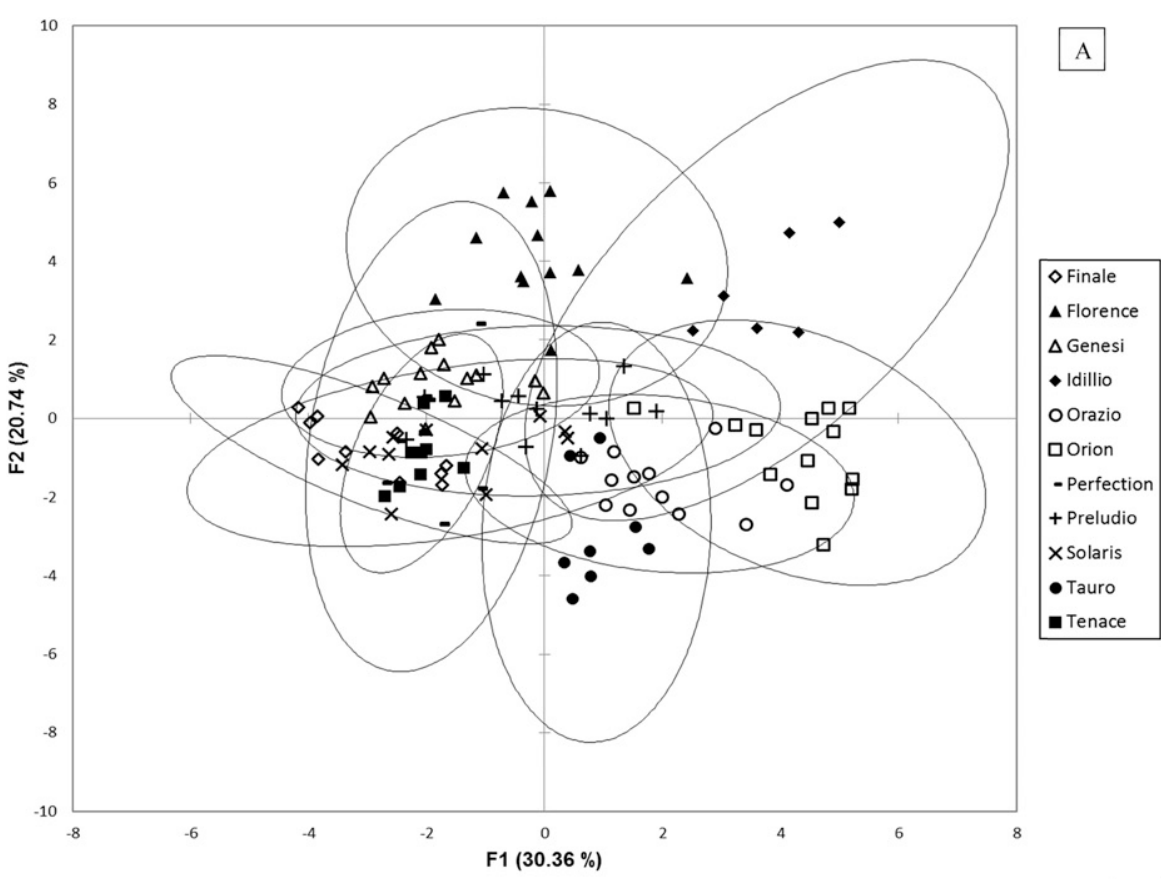

B

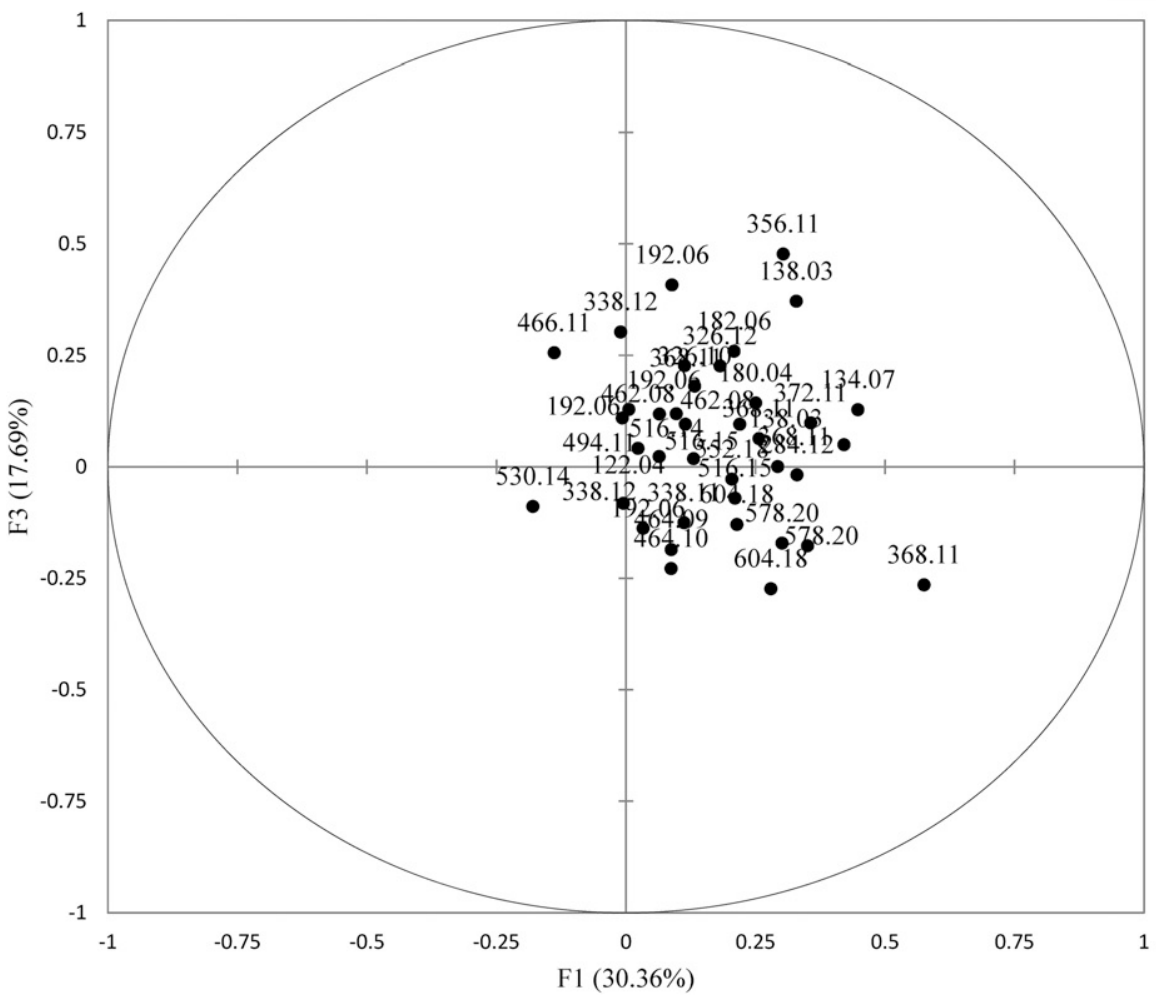

Fig. 5. (A) Score plot for 11 bulb fennel cultivars (Finale, Florence, Genesi, Idillio, Orazio, Orion, Perfection, Preludio, Solaris, Tauro, and Tenace). Ellipses represent the $\mathbf{9 5 \%}$ confidence level for each sample class; ellipses that overlap are not significantly different from one another $(P<0.05)$. (B) Loading plot for discriminant analysis showing accurate mass data for compounds associated with each of the 11 bulb fennel cultivars. Mass data are truncated to two places after the decimal point and retention times are not shown for clarity. Principal component 1 (PC1) and principal component 2 (PC2), which are uncorrelated variables, capture the greatest variation in the dataset. did not differ due to seeding date $(P=$ $0.05)$, but there was a difference due to cultivar (Table 5). 'Tauro' had a higher rating (1.8) than 'Finale' (0.9), although neither rating indicated a negative impact on marketability. None of the interactions of main factors were significant sources of variation for branching (data not shown), but branching was found to differ due to cultivar, with Zefa Fino rated higher (2.5) than Finale and Tauro (1.6 on average) (Table 5); however, again, none had levels that impacted marketability. The interaction of cultivar $\times$ planting method was significant for internal cracking incidence, and transplanted 'Tauro' had a higher incidence of internal cracking $(21 \%)$ than all other cultivar $\times$ planting method interactions ( $3 \%$ on average) (Table 4). Transplanted 'Tauro' exhibited an incidence of internal cracking similar to that observed during study one in 2018 (17.5\%), suggesting that this cultivar is prone to this issue. Although bulb tenderness did not differ due to cultivar $(P=$ 0.63 ), the interaction of seeding date $x$ planting method was found to be significant (Table 6). Direct seeding on 17 and 31 May resulted in a less tender bulb (711 g-force, on average) than transplanting on all dates $(548$ $\mathrm{g}$-force, on average). The overall SSC in this study was $4.5 \%$, and none of the main effects or interactions differed (data not shown), just as in the first study.

\section{Conclusions}

Days until harvest were similar for the second study and year 2 of study one, indicating that seeding bulb fennel in mid-April until midJune is well-suited for production in northwest Washington. Bulb fennel seeded later in June had a lower bulb production rate due to bolting, which was the primary reason why plants were not harvested regardless of cultivar, seeding date, and planting method. High temperatures, a sudden drop in temperature, insufficient water, and change in daylength can all induce bolting in bulb fennel, and resistance to bolting has been bred into some cultivars. Direct seeded bulb fennel required fewer days to harvest than transplanted bulb fennel, and direct seeding is generally preferred by growers due to reduced cost compared with transplants. During 
Table 4. Days until the first harvest, bulb production rate, and incidence of internal cracking rating observed for three bulb fennel cultivars direct seeded (DS) or transplanted (T) in the field in northwest Washington on four seeding dates in 2018.

\begin{tabular}{|c|c|c|c|c|c|c|c|}
\hline \multirow[b]{3}{*}{ Cultivar } & \multirow[b]{3}{*}{ Planting method } & \multicolumn{4}{|c|}{ Seeding date } & \multirow[b]{3}{*}{ Bulb production rate $(\%)^{\mathrm{z}}$} & \multirow[b]{3}{*}{ Internal cracking $(\%)^{\mathrm{y}}$} \\
\hline & & 17 May & 31 May & 14 June & 28 June & & \\
\hline & & \multicolumn{4}{|c|}{ Time to first harvest (d) } & & \\
\hline \multirow[t]{2}{*}{ Finale } & DS & $89 b^{x}$ & $90 \mathrm{~b}$ & $98 \mathrm{~b}$ & $98 \mathrm{~b}$ & $82 a^{x}$ & $4 \mathrm{~b}$ \\
\hline & $\mathrm{T}$ & $110 \mathrm{ab}$ & $130 \mathrm{a}$ & $112 \mathrm{a}$ & $121 \mathrm{a}$ & $73 a$ & $4 \mathrm{~b}$ \\
\hline \multirow[t]{2}{*}{ Tauro } & DS & $89 \mathrm{~b}$ & $90 \mathrm{~b}$ & $98 \mathrm{~b}$ & $94 \mathrm{~b}$ & $86 \mathrm{a}$ & $5 \mathrm{~b}$ \\
\hline & $\mathrm{T}$ & $107 \mathrm{ab}$ & $130 \mathrm{a}$ & $131 \mathrm{a}$ & $121 \mathrm{a}$ & $79 \mathrm{a}$ & $21 \mathrm{a}$ \\
\hline & $P$ value & \multicolumn{4}{|c|}{$0.02^{\mathrm{w}}$} & 0.01 & 0.03 \\
\hline
\end{tabular}

${ }^{\mathrm{z}}$ Bulb production rate calculated as the total number of bulbs formed divided by total number of plants (reported as percentage).

y Internal cracking scored as absent or present; the incidence of internal cracking was calculated as the number of bulbs in which internal cracking was recorded as present divided by the total number of bulbs evaluated.

${ }^{x}$ Different letters within a column indicate differences in means as compared by Tukey's honest significant difference test at a $5 \%$ level of significance.

w Probability value for the interaction of planting method by seeding date.

Table 5. Yield, basal cracking, and branching for three bulb fennel cultivars grown in northwest Washington in 2018.

\begin{tabular}{lccc}
\hline Cultivar & Yield $(\mathbf{l b} / \mathbf{a c r e})^{\mathrm{z}}$ & Basal cracking $(\mathbf{0}-\mathbf{5})^{\mathrm{y}}$ & ${\text { Branching }(\mathbf{0}-\mathbf{5})^{\mathrm{y}}}^{\mathrm{y}}$ \\
\hline Finale & $19,632 \mathrm{a}^{\mathrm{x}}$ & $0.9 \mathrm{~b}$ & $1.3 \mathrm{~b}$ \\
Tauro & $17,41 \mathrm{a}$ & $1.8 \mathrm{a}$ & $1.8 \mathrm{~b}$ \\
Zefa Fino & $6,810 \mathrm{~b}$ & $1.4 \mathrm{ab}$ & $2.5 \mathrm{a}$ \\
$P$ value & 0.003 & 0.0003 & $<0.0001$ \\
\hline
\end{tabular}

${ }^{z}$ Yield calculated by multiplying the estimated production potential constant of 48,214 [the maximum number of bulbs per acre when spacing is 8 inches $(20.3 \mathrm{~cm})$ in-row, two rows per bed, and $5 \mathrm{ft}(1.5 \mathrm{~m})$ between beds] by the measured bulb weight and calculated bulb production rate; $1 \mathrm{lb} / \mathrm{acre}=1.1209 \mathrm{~kg} \cdot \mathrm{ha}^{-1}$.

${ }^{y}$ Basal cracking and branching were graded on a scale of 0 to 5 , where $0=$ no condition observed, $1=$ very good (slight signs of basal cracking or branching), 2 = good (signs are visible, no impact on marketing), $3=$ acceptable (moderate signs of basal cracking or branching, may impact marketing), 4 = poor (serious condition, may still be marketable after removing outside cracked leaves or extra branches), and $5=$ very poor (the condition was very serious, bulb would not be marketable).

${ }^{\mathrm{x}}$ Different letters within a column indicate differences in means as compared by Tukey's honest significant difference test at a $5 \%$ level of significance.

Table 6. Bulb production rate, bulb circumference, and tenderness for bulb fennel direct seeded (DS) or transplanted (T) in the field in northwest Washington on four seeding dates in 2018.

\begin{tabular}{lcccc}
\hline $\begin{array}{l}\text { Seeding } \\
\text { date }\end{array}$ & $\begin{array}{c}\text { Planting } \\
\text { method }\end{array}$ & $\begin{array}{c}\text { Bulb production } \\
\text { rate }(\%)^{\mathbf{z}}\end{array}$ & $\begin{array}{c}\text { Bulb } \\
\text { circumference } \\
(\mathbf{c m})^{\mathbf{y}}\end{array}$ & $\begin{array}{c}\text { Tenderness } \\
(\text { gram-force) }\end{array}$ \\
\hline 17 May & DS & $64 \mathrm{ab}^{\mathbf{w}}$ & $29.6 \mathrm{a}$ & $727 \mathrm{a}$ \\
31 May & $\mathrm{T}$ & $77 \mathrm{a}$ & $27.6 \mathrm{abc}$ & $514 \mathrm{c}$ \\
& $\mathrm{DS}$ & $78 \mathrm{a}$ & $26.6 \mathrm{bc}$ & $695 \mathrm{ab}$ \\
14 June & $\mathrm{T}$ & $72 \mathrm{ab}$ & $29.7 \mathrm{a}$ & $586 \mathrm{bc}$ \\
& $\mathrm{DS}$ & $68 \mathrm{ab}$ & $28.7 \mathrm{ab}$ & $609 \mathrm{abc}$ \\
28 June & $\mathrm{T}$ & $58 \mathrm{ab}$ & $28.8 \mathrm{ab}$ & $552 \mathrm{c}$ \\
& $\mathrm{DS}$ & $48 \mathrm{~b}$ & $29.5 \mathrm{ab}$ & $625 \mathrm{abc}$ \\
Pvalue & $\mathrm{T}$ & $65 \mathrm{ab}$ & $25.6 \mathrm{c}$ & $541 \mathrm{c}$ \\
\hline
\end{tabular}

${ }^{\mathrm{z}}$ Bulb production rate calculated as the total number of bulbs formed divided by total number of plants and reported as percentage.

${ }^{\mathrm{y}}$ Bulb circumference was calculated using the Ramanujan II approximation of the perimeter of an ellipse: $p \approx \pi(a+b)\left(1+\frac{3 b}{10+\sqrt{4}-3 b}\right)$, where $b=\frac{(a-b)^{2}}{(a+b)^{2}}$ and $a=\frac{\text { Diameter }}{2}$ and $b=\frac{\text { Width }}{2} ; \mathrm{cm}=0.3937$ inch.

${ }^{\mathrm{x}} \mathrm{l} \mathrm{g}$-force $=0.0022 \mathrm{lbf}$.

wDifferent letters within a column indicate differences in means as compared by Tukey's honest significant difference test at a $5 \%$ level of significance.

the first study, the difference in bulb circumference was negligible in 2017 compared with $2018(0.7 \mathrm{~cm})$, and total yield was less in 2017 despite the harvest being 1 month later. These results indicated there is no yield advantage to delaying harvest beyond a threshold bulb circumference. At this location, the bulb circumference was $28.1 \mathrm{~cm}$ on average for both studies, with little variation among productive cultivars or between years (range, 25.6-29.7 cm).

Similar to many fresh market vegetable crops, growers will harvest a bulb fennel field one time; therefore, uniform timing of bulb formation is an important factor impacting bulb fennel yield and profitability for the grower. Cultivars Finale, Orazio, Preludio, Solaris, Tauro, and Tenace had the best bulb productivity both years, indicating they are well-suited for this location, but cultivars Bronze, Florence, Idillio, and Zefa Fino did not produce bulbs consistently. 'Genesi', 'Orion', and 'Perfection' were productive 1 year of the 2 years, indicating that they may be more susceptible to environmental and management influences. The quality of fennel bulbs was good for all cultivars in both studies. Of the cultivars that were most productive in these studies, only 'Tenace' had basal cracking that could impact marketability (3.3 in 2018), whereas 'Tauro' exhibited internal cracking (incidence up to $21 \%$ ). Less tender bulbs in 2017 than in 2018 in the first study likely was due to the difference in days to harvest because bulbs in 2017 were harvested 1 month later than in 2018. This result and the lack of gain in bulb circumference or yield support the finding that harvesting bulbs as soon as they reach the desired bulb circumference produces a greater yield of higher-quality bulbs. Bulb tenderness for both studies in 2018 was $617 \mathrm{~g}$ force on average, and the overall SSC of bulbs in both studies was $4.9 \%$, although it is not clear how these measures compare with bulb fennel 
production in other regions because no data have been reported. Phenolic content was similar for most cultivars, with generally larger variations within a cultivar than between cultivars, suggesting that additional evaluations of the phenolic composition in future studies would be necessary before phenolic composition could be established as a basis for cultivar selection.

Production practices may have impacted productivity in these studies. Crop yield increase in 2018 compared with 2017 may have been due to splitting supplemental $\mathrm{N}$ fertilizer into three applications $10 \mathrm{~d}$ apart in 2018 compared with a single application in 2017, and also to slightly increasing the amount of $\mathrm{N}$ fertilizer applied overall in $2018 \times 1.2 \mathrm{lb} /$ acre N. Therefore, the fertilizer amount and timing warrant further investigation. Weed control is very important for organic bulb fennel production because the crop is difficult to weed by hand. Organic growers in the region have reported that their bulb fennel crop is a poor competitor with weeds. In this study, conventional herbicides were very effective; however, their application resulted in the loss of organic certification for the field site for 3 years. Plastic mulch was effective for controlling weeds in this study except in the planting hole. Our experience combined with grower reports demonstrated the need for weed-free fields for organic bulb fennel production. Finally, the days until the first bulb fennel harvest in our studies were, on average, $37 \mathrm{~d}$ later than the first harvest dates provided by seed companies (data not shown), likely due to relatively cool temperatures during the summer growing season in northwest Washington. Growers should be aware that days until harvest may differ due to the production region. These studies demonstrated that bulb fennel production is suitable for some cultivars in northwest Washington. Future studies should further explore seeding dates, supplemental fertilizer applications, and weed management practices for organic systems to improve the bulb production rate and quality. Furthermore, consumer awareness is needed to increase sales and consumption of bulb fennel in the United States.

\section{Literature cited}

Aaby, K., G. Skrede, and R.E. Wrolstad. 2005. Phenolic composition and antioxidant activities in flesh and achenes of strawberries (Fragaria ananassa). J. Agr. Food Chem. 53:4032-4040.

Badgujar, S.B., V.V. Patel, and A.T. Bandivdekar. 2014. Foeniculum vulgare Mill: A review of its botany, phytochemistry, pharmacology, contemporary application and toxicology. BioMed Res. Intl. 2014:1-32.

Barros, L., A.M. Carvalho, and I.C.F.R. Ferreira. 2010. The nutritional composition of fennel (Foeniculum vulgare): Shoots, leaves, stems and inflorescences. Lebensm. Wiss. Technol. 43:814-818.

Bower, A., S. Marquez, and E.G. de Mejia. 2016. The health benefits of selected culinary herbs and spices found in the traditional Mediterranean diet. Crit. Rev. Food Sci. Nutr. 56:2728-2746.

Cserni, I., A. Huvely, and J.B. Peto. 2011. Production and quality of fennel. Acta Universitatis Sapientiae Agr. Environ. 3:132-143.

Dongare, V., C. Kulkarni, M. Kondawar, C. Magdum, V. Haldavnekar, and A. Arvindekar. 2012. Inhibition of aldose reductase and anti-cataract action of transanethole isolated from Foeniculum vulgare Mill. fruits. Food Chem. 132:385-390.

Faudale, M., F. Yiladomat, J. Bastida, F. Poli, and C. Codina. 2008. Antioxidant activity and phenolic composition of wild, edible, and medicinal fennel from different mediterranean countries. J. Agr. Food Chem. 56:1912-1920.

Ferioli, F., E. Giambanelli, and L.F. D'Antuono. 2017. Fennel (Foeniculum vulgare Mill. subsp. piperitum) florets, a traditional culinary spice in Italy: Evaluation of phenolics and volatiles in the local population, and comparison with the composition of other plant parts. J. Sci. Food Agr. 97:5369-5380.

Frost, J. 2015. 9 Tips for growing great fennel. 26 Jan. 2019. <http://www. hobbyfarms.com/9-tips-for-growinggreat-fennel-2/>.

Kitajima, J., T. Ishikawa, and Y. Tanaka. 1998. Water-soluble constituents of fennel. II. Four erythro-anethole glycol glycosides and two p-hydroxyphenylpropylene glycol glycosides. Chem. Pharmaceutical Bul. 46:1591-1594.

Kurtz, E.A. and E. Mora. 2000. Crop profile for fennel in California. 26 Jan. 2019. <https://ipmdata.ipmcenters. org/documents/cropprofiles/CAfennel. pdf $>$.

Pacifico, S., S. Galasso, S. Piccolella, N. Kretchmer, S. Pan, P. Nocera, A. Lettieri, R. Bauer, and P. Monaco. 2018. Winter wild fennel leaves as a source of anti-inflammatory and antioxidant polyphenols. Arab. J. Chem. 11:523-524.

Pouryousef, M. 2014. Variation in the essential oil constituents in indigenous populations of Foeniculum vulgare var. vulgare from different locations in Iran. J. Essent. Oil Res. 26:441-445.

Rather, M.A., B.A. Dar, S.N. Sofi, B.A. Bhat, and M.A. Qurishi. 2016. Foeniculum vulgare: A comprehensive review of its traditional use, phytochemistry, pharmacology and safety. Arab. J. Chem. 9:S1574-S1583.

Scripps Research. 2019. METLIN Metabolomics database. 3 Mar. 2019. <https:// metlin.scripps.edu/landing_page.php? pgcontent $=$ mainPage $>$.

Washington State University. 2019. AgWeather Net. 26 Aug. 2017. <http:// weather.wsu.edu/?p=93050>.

Weatherbase. 2017. Monthly weather averages for Catania, Sicily, Italy. 23 Aug. 2017. <http://www.weatherbase.com/ weather $/$ weather.php 3 ? s $=6461 \&$ cityname $=$ Catania-Sicily-Italy $>$.

Zheng, W. and M.N. Clifford. 2008. Profiling the chlorogenic acids of sweet potato (Ipomoea batatas) from China. Food Chem. 106:147-152. 